\title{
Agricultural Credit Access by Grain Growers in Uasin-Gishu County, Kenya.
}

\author{
Yegoh Kenneth Kimeli Kosgey \\ Residential address with Pin Code: Moi University, P.O BOX 3900-30100, Eldoret- Kenya.
}

\begin{abstract}
Generally in Kenya, lack of finances is one of the critical problems hindering growth, production, productivity and generation of income of farm income. Indeed inaccessibility to agricultural credit by grain growers in Uasin-Gishu County, has contributed to the low and declining use of farm inputs resulting in a fall in agricultural productivity leading to low outputs and depressed farmers income. The study examined factors influencing accessibility to agricultural credit. The study was conducted in Uasin-Gishu County, Kenya, using a survey design. The research examined 130 grain farmers, interviewed $1 \mathrm{~K}$-Rep officer and 2 officers from Agricultural Finance Corporation (AFC). Interviews, structured questionnaires, observation and document analysis, were used to collect quantitative data from the sampled households. Descriptive and binary logit model were used to analyze quantitative and qualitative data. The results revealed that 47 (36.8 per cent) of the sampled grain farmers accessed agricultural credit, whereas the remaining 83 (63.8 per cent) did not access credit. It was also found that agricultural credit access by female farmers is still very limited. Generally, farmers' age, education level, family size, household size, repayment period and applied loan were highly important in influencing access to agricultural credit. Therefore, a policy be adopted where extension officers from the ministry of Agriculture do an exhaustive database on socio-economic status of all grain farmers in the County.

Key Words: Accessibility, Binary Logit, Credit, Grain,
\end{abstract}

\section{Introduction}

Kenya's economy is largely agro-based with the agricultural sector accounting for 26 per cent of the Gross domestic product (GDP) and 60 per cent export earnings (G.O.K, 2010). In addition, agriculture indirectly contributes 27 per cent to the country's GDP through manufacturing and service related sectors (G.O.K, 2010). The sector employs more than 80 per cent of Kenya's work force and contributes about 57 per cent of the national income both directly and indirectly. Agricultural credit enhances productivity and promotes standard of living by breaking a vicious cycle of poverty for small-scale farmers.

Adegeye; and Ditto (1985) described agricultural credit as the process of obtaining control over the use of money, goods and services in the present in exchange for a promise to repay at a future date. Hence, the crucial role of credit in agricultural production and development can be appraised also from the perspective of the quantity of problems emanating from the lack of it. Agricultural credit is a temporary substitute for personal savings, which catalyses the process of agricultural production and productivity.

Although in the past 40 years, billions of dollars were spent to support the Green revolution, recently there is migration of funding away from agricultural projects. For example, agriculture accounted for 31 per cent of World Bank lending in 1979 - 1981, but by 2000-2001, it had fallen to 10 per cent (Christen and Pearce, 2005). This decrease in lending for strictly agricultural projects was due in part to an increase in support for return and the strengthening of overall financial markets. A similar shift of funding also occurred in the InterAmerican Development Bank, the European Bank of Reconstruction and Development and the Asian Development Bank.

The same scenario was replicated by African Development Bank, which actually confirmed that the rural agricultural poor are constrained from accessing agricultural credit. Farmers in Sub-Sahara Africa lagged behind in technology use, that would help them add value to their products, fetch higher prices in the domestic and export markets due to capital deficiency (Lynam, 2007). Credit is a very important component in the modernization of agricultural activities. Since modern technology is expensive, farmers resort to credit in order to finance different agricultural operations. Nevertheless, farm credit is not only, necessitated by the limitations of self-finance but also by uncertainty pertaining to the level of output and time lag between inputs and outputs (De- Janvry and Sadoulet, 1995). Recent studies have shown that the growth rate of agricultural investment is less than growth of other economic sectors, implying that agricultural financing is one of the most important factors needed to develop rural agriculture in developing countries. Therefore, there is need for facilitation of access to agricultural credit, in order to raise amount of productive investment thereby playing a crucial role in elimination of farmers' financial constraints for investment in farm activities, increasing productivity and improving farm technologies. 
In Kenya, accessibility to agricultural credit by farmers has been dwindling over time. The Ministry of Agriculture does not have a clear policy to deal with the problem hence leaving the task to credit institutions to provide finances to farmers at their own prerogative. Therefore, with the presence of financial institutions like the Agricultural Finance Corporation (AFC), K-Rep and Equity Bank playing the role of advancing loans to farmers, a problem arises on credit accessibility at affordable rates.

Indeed the trend for the last nine years in agricultural credit dispersed to the grain farmers has been declining in the County. In 2004 to 2012 accessibility to agricultural credit dropped from 57.17 percent to 18.74 percent indicating that there is a problem since the number of applicants has been increasing over the same period whereas unsuccessful applicants have been increasing as shown in table 1.1.

Table 1.1: Trends of Agricultural Credit in Uasin-Gishu County by AFC from 2004 - 2012

\begin{tabular}{|c|c|c|c|c|c|c|}
\hline Years & $\begin{array}{l}\text { Credit demand } \\
\text { (Kshs) }\end{array}$ & $\begin{array}{l}\text { Number of } \\
\text { Applicants }\end{array}$ & $\begin{array}{l}\text { Credit supply } \\
\text { (Kshs) }\end{array}$ & $\begin{array}{l}\text { Successful } \\
\text { Applicants }\end{array}$ & $\begin{array}{l}\text { Unsuccessful } \\
\text { Applicants }\end{array}$ & $\begin{array}{l}\text { \% of Credit } \\
\text { disbursed }\end{array}$ \\
\hline 2004 & $250,000,000$ & 1,270 & $138,299,600$ & 729 & 541 & 57.1 \\
\hline 2005 & $370,500,000$ & 2,470 & $164,432,250$ & 820 & 1,650 & 33.2 \\
\hline 2006 & $500,200,000$ & 3,340 & $233,080,850$ & 1,092 & 2,248 & 32.6 \\
\hline 2007 & $430,350,000$ & 2,800 & $210,392,200$ & 840 & 1,960 & 30.0 \\
\hline 2008 & $540,637,000$ & 3,600 & $124,672,900$ & 497 & 3,207 & 23.06 \\
\hline 2009 & $588,490,000$ & 4,005 & $130,300,000$ & 654 & 3,451 & 22.14 \\
\hline 2010 & $665,050,000$ & 4,268 & $142,480,000$ & 728 & 3,540 & 21.42 \\
\hline 2011 & $720,108,000$ & 4,890 & $150,400,500$ & 806 & 4,084 & 20.89 \\
\hline 2012 & $833,590,000$ & 5,200 & $156,200,000$ & 850 & 4,350 & 18.74 \\
\hline
\end{tabular}

Source: AFC Eldoret Branch, 2012

\subsection{THEORETICAL CONCEPTS AND DEFINITIONS}

\section{Literature Review}

The concept of perception, according to Lindsay \& Norman (1977), is what better describes one's ultimate experience of the world and typically involves further processing of sensory input. As stated by Rao et al., (1998), the interpretation of information is called perception. These perceptions play an important role in decision making of people in general and farmers are no exception. Perceptions are relative rather than absolute and they are influenced by the surroundings to a great extent.

Kebede (1995), credit makes traditional agriculture more productive through the purchase of farm equipment and other agricultural inputs, the introduction of modern irrigation system and other technological developments. Credit can also be used as an instrument for market stability. Rural farmers can build their bargaining power by establishing storage facilities and providing transport system acquired through credit. Credit plays a key role in covering consumption deficits of farm households. This would, in turn, enable the farm family to work efficiently in agricultural activities. Credit can further be used as an income transfer mechanism to remove the inequalities in income distribution among the small, medium, and large scale farmers. Moreover, credit encourages savings and savings held by financial institutions that could be channeled to farmers for use in agricultural production. Credit also creates employment opportunities for rural farmers.

According to the free on line dictionary, Encyclopedia (2007), credit means Faith and it comes from the Latin word credito. An agreement, by which something of value-goods, services, or money-is given in exchange for a promise to pay at a later date. Credit is a transaction between two parties in which one, acting as creditor or lender, supplies the other, the debtor or borrower, with money, goods, services, or securities in return for the promise of future payment.

\subsection{TYPES OF AGRICULTURAL CREDIT}

The establishment of formal credit institutions in the agricultural-based developing economies some 40 or more years ago was, among other reasons linked to the belief that local or informal lenders such as merchants, landlords and shop owners exploit small-scale farmers by charging them exorbitant interest rates (Adams, 1984). This observation is contrary to the Kenyan context, where relatives or friends may extend credit to their relatives or friends (farmers) that attract zero interest. Similarly, Kenya shop owners give goods on credit to some customers who have demonstrated to be trustworthy and pay at a later date with no interest. This practice does not favour Kenyan poor farmers, since they are assumed to have high risks in repaying credit in future. The study dwelled on informal credit as opposed to formal credit which the current study has focused on. The informal rural credit market is very heterogeneous and is always a component of the prevailing political, economic, and social relations net work, involving relatively low additional transaction costs for credit supply. 
The informal credit market was mainly relevant only for sectors that were not directly productive and through which the expenditure for social obligations was met (Manig, 1996).

In Kenya, a number of financial institutions are dealing with agricultural credit to the vast populace. The active ones include; Agricultural Finance Corporation, K-Rep, Equity bank, Faulu Kenya, KADET and a number of farmers' Co-operative societies.

\subsection{FARMERS ACCESS TO AGRICULTURAL CREDIT}

Penchansky and Thomas, (1981), stated that "to some authors "access" refers to entry into or use of the health care system, while to others it characterizes factors influencing entry or use." Moreover, according to the Oxford dictionary (2007), access can be defined as, the right to obtain or make use of or take advantage of something.

Diagne et al., (2000) stated that a household is said to have access to a type of credit if at least one of its members has a strictly positive credit limit for that type of credit. Similarly, a household is classified as credit constrained for a type of credit if at least one of its members is constrained for that type of credit. In the current study a household is not credit constrained if one of its members has failed to access credit, while the rest have succeeded. This leaves a gap to be researched on so as to establish at what level a specific household is credit constrained.

Access to financial services by smallholders is seen as one of the constraints limiting their benefits from credit facilities. However, in most cases the access problem, especially among formal financial institutions, is one created by the institutions mainly through their lending policies. This is manifested in the form of prescribed minimum loan amounts, complicated application procedures and restrictions on credit for specific purposes (Schmidt and Kropp, 1987). For small-scale enterprises, reliable access to short-term and small amounts of credit is more valuable, and emphasizing it may be more appropriate in credit programmes aimed at such enterprises.

Women are frequently discriminated against in formal credit markets in developing countries (Buvinic et al, 1990). The belief in discrimination against women in formal credit markets, often based upon the limited number of women borrowers in the market, is perceived as an outcome of lenders' rejection of women's applications for loan contracts. Over a decade ago, Buvinic, et al (1990) emphasized that women's lack of control over economic resources and the nature of their economic activity restrict accessing formal credit more than men.

According to Zeller (1994), when taking credit is perceived as a decision making process, then it starts with the decision of the individual to apply for credit. In fact, the demand for loans depends on the selffinancing potential, access to credit facilities and risk taking ability of borrowers. Demand is an important factor to access credit.

\subsection{EMPIRICAL STUDIES ON DETERMINANTS OF ACCESS TO CREDIT}

Kashuliza and Kydd, 1996; Zeller, 1994 did a study on determinants of bank credit access for small holder farmers in Tanzania: A discriminant analysis application. In their findings characteristics of the borrowers and conditions of the financial institutions greatly influences the credit access. Whereas their study was conducted in a bigger sample size, they only concentrated on small holder farmers' as opposed to all holders and with specific crops. Indeed, the study is relevant to the current study since both assume socioeconomic factors to determine farmer's access to agricultural credit but the difference is on the model used (binary logit) and type of farmers ( grain).

Schmidt and Kropp (1987) revealed that the type of financial institution and its policy will often determine access. Where credit duration, terms of payment, required security and the provisions of supplementary services do not fit the needs of the target group, potential borrowers will not apply for credit even where it exists and when they do, they will be denied access. In addition, Bigsten et al. (2003), and Fliesig (1995), stated that in developing countries asymmetric information, high risks, lack of collateral, lenderborrower distance, small and frequent credit transactions of rural households make real costs of borrowing vary among different sources of credit. These studies were on the power of collateral, determinants of household access to and participation in formal and informal credit markets in Malawi. These are true with most Kenyan financial institutions, where loans are advanced to farmers at the start of planting season and expect them to repay at harvesting time. Therefore, terms of payment in the Kenyan setup are strict and not flexible as compared to Malawian credit institutions. In this study the collateral required in credit institutions was a title deed or a registered farmers group with clean records.

Atieno (2001), did an empirical assessment on the formal and informal institutions' lending policies and access to credit by small-scale enterprises in Kenya. The findings showed that income level, distance to credit sources, past credit participation and assets owned were significant variables that explain participation in formal credit markets. Indeed, the study dealt with both formal and non formal lending institutions in relation to 
small scale enterprises in accessing general credit. But the current study only concentrated on grain farmers' access to formal agricultural credit.

Also, Hussein (2007), Padmanabhan (1996) and Hossain (1988), did a study on flexibility of repayment period, credit access and management of collaterals or flexibility in collateral requirements, repayment period and reduced transaction costs. They found out that flexible repayment period was favoured by most farmers' whom they interviewed. The management of collateral security by most institutions is slowly changing with new approaches like registered farmers groups accessing agricultural credit without giving out title deeds as a collateral security.

A study in Egypt by Mohieldin and Write (2000), employing a probit model analysis of the formal credit sector shows the impact of the explanatory variables on the outcome of whether a person has a loan or not. Both the requirements of the individual (demand side) and of the lending institution (supply side) determined whether a loan is enough. The results of the study indicated that educational level, ownership of land, total assets, and sizes of the household were significant factors. The variables considered in the study, really determine whether the person has credit or not are the same as those employed in the current study. The difference was on the model (binary logit) and the total assets which to the current study only considered land with a title deed. In Kenyan context loans are advanced to those who have applied and not everybody.

In an empirical study of repayment performance in group-based credit programs in Bangladesh, Sharma and Zeller (1996) found that social capital results in very high repayment rates compared to traditional physical collateral based financial institutions. In the current study individual loans of grain farmers' were analyzed. High repayments were registered in cases where farmers arrange for a flexible repayment schedule with financial institutions as opposed to fixed one.

Okurut, et al (2005) employed a logit model to investigate factors that influence both credit demand and supply in Uganda by using observed household and individual characteristics. The household characteristics that influenced demand included age, education, and household expenditure per adult equivalent. They further argued that, household composition, migration status and credit demand is higher for males than females and for households with a higher dependency ratio, demand for credit is less in households with sick members and more land assets per adult equivalent, while gender does not play a significant role in the demand for credit. The current study employed binary logit model and investigated grain farmers in Kenya.

\section{Justification Of The Study}

The lack of capital and the absence of attractive investment opportunities are considered to be important reasons behind inadequate economic development in many developing countries. This is why an attempt is made in most developing countries to encourage, through development policy measures, capital formation as well as the supply of financial means in the form of credit through official financial institutions (Manig, 1996). Because of the lack of access to credit in the formal sector, productive assets of the poor are depleted; assets used as collateral are transferred from the poor to wealthier informal lenders, and households may become impoverished.

Therefore, the outcome of the study would be useful to identify options and institutional arrangements that would serve as an input for policy makers in formulating rural credit policy. The study will also provide useful information on the status of grain growers in accessing agricultural credit from existing financial institutions in Uasin-Gishu County. The research would also assist the government in addressing the perennial inadequacy of funds to finance the grain sub-sector, so that the country becomes self sufficient in food and surplus for export in order to get the much needed foreign exchange.

\section{Statement Of The Problem}

While there is no doubt that commercialization of agricultural production in Uasin-Gishu County requires heavy capital investment among cereal growers, low accessibility to credit negates any efforts aimed at reversing declining cereal sector productivity. Indeed the county has witnessed a declining trend in production of the major cereals. Maize production dropped from 2,827,594 bags in 2005 to 1,967,805 bags in 2012 while, wheat output declined from 1,263,460 bags in 2004 to 1,080,071 bags in 2012 (DAO Uasin-Gishu County 2012). The same trend was reported in Credit access which dropped from 57.17 percent to 18.74 percent in 2004 to 2012 respectively.

Difficulties among grain growers to access credit calls for an evaluation of the underlying causes hence, raising the following question; what socio-economic factors influence accessibility to agricultural credit by grain farmers in Uasin-Gishu County?

\section{Objective Of The Study}

1. To identify factors influencing accessibility to Agricultural credit by grain growers in Uasin-Gishu County. 


\section{Hypotheses}

$\mathrm{H}_{01}$ : Socio-economic factors such as age, gender, education, income sources, land size, family size, marital status, grain yields, land ownership, repayment period, interest rate, lack of security, farmers who applied for credit and those who receive credit have no influence on grain growers' chances of accessing agricultural credit.

\subsection{STUDY AREA}

\section{Research Methodology}

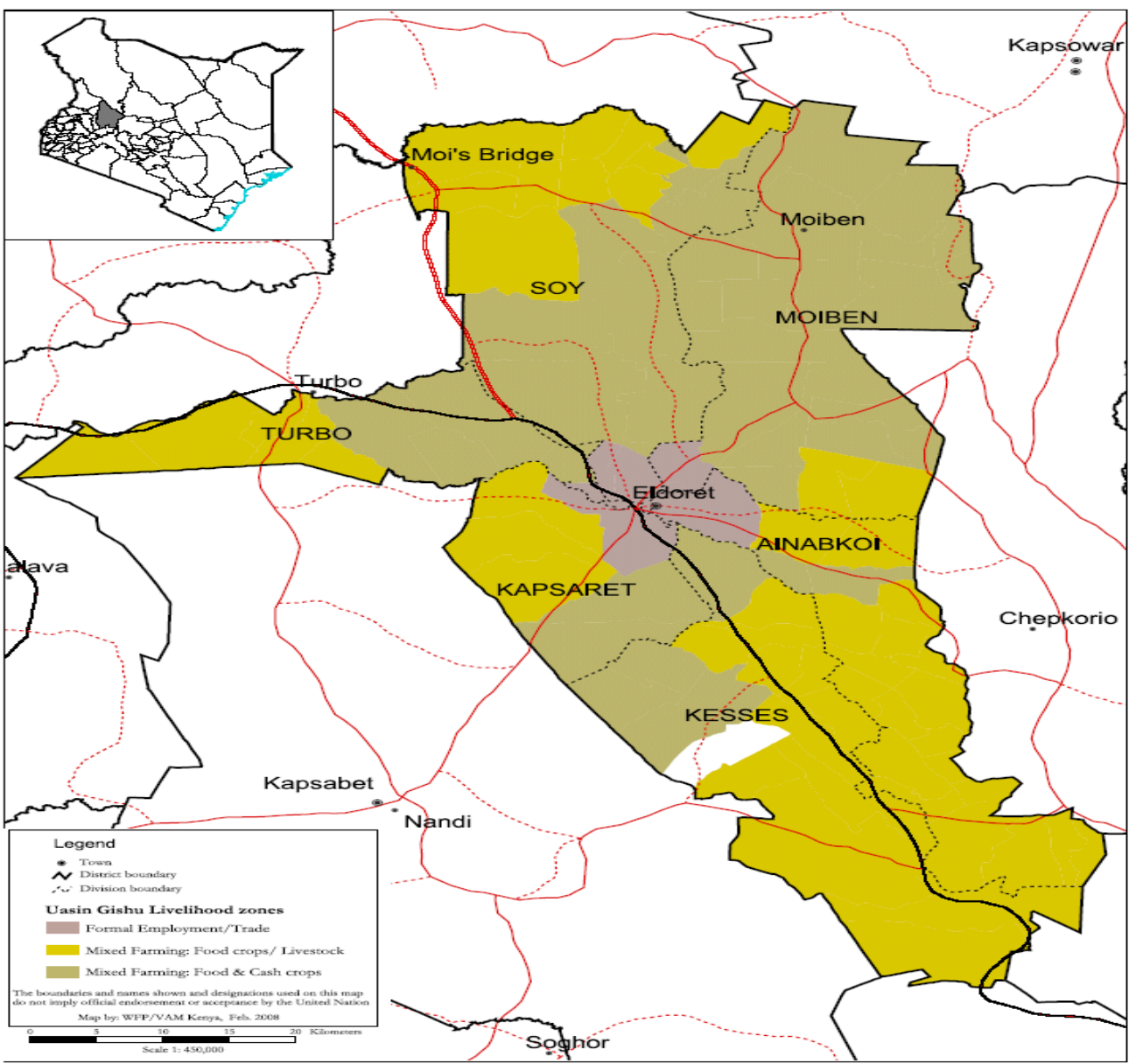

Figure 7.1 Map of Uasin-Gishu County, Kenya

Source: DAO, 2012

The study was conducted in Uasin-Gishu County, which shares common borders with Trans-Nzoia County to the North, Bungoma County to the North West, Nandi County to the West, Elgeyo -Marakwet County to the East, Baringo County to the South East and Kericho County to the South. It lies between longitude $34^{\circ} 50^{\prime}$ to $35^{\circ}$ $37^{\prime}$ 'East, and on latitude $0^{\circ} 03^{\prime}$ 'south to $0^{\circ} 05^{\prime}$ 'North. According to the Uasin-Gishu County development plan (2000-2004), the County's total area is 3,218 square kilometers. Its terrain varies greatly with the altitude that ranges from 1,500 meters above sea level at Kipkaren to 2,100 meters above sea level at Timboroa in the east. Temperatures range between 7 degrees to

25 degrees while the rainfall averages 960 millimeters, which is reliable and evenly distributed. The County comprises of 6 Constituencies/divisions, 51 locations and 96 sub-locations and its major farming activities are farming of maize, wheat and dairy rearing across the upper highland 1, 3, 4 and the lower highland 3 and 4 agro-ecological zones.

\subsection{MODEL SPECIFICATION}

An econometric model was employed to analyze the data on farmers' accessibility to agricultural credit in Uasin-Gishu County. The two most common functional forms used in adoption studies are the logit and the probit models. The advantage of these models is that the probabilities are bounded between 0 and 1 . The dependent variable is dichotomous taking two values, 1 if the event occurs and 0 if it doesn't. Models, which include a "yes" or "no" type dependent variable, are called dichotomous (binary). Such models approximate the 
mathematical relationships between explanatory variables and the dependent variable that is always assigned qualitative response. For that reason this study adopted the binary logit model, which is also consistent and more robust in handling both the qualitative and quantitative variables.

\subsection{RESEARCH DESIGN}

Literature search, administration of questionnaires and observations were used in collecting data. In the study a survey design targeting all the grain farmers in Uasin-Gishu County who had applied for the loan was employed. Stratified sampling was used to select sub-groups (small, medium and large scale-holders) from the target population of grain farmers in Uasin-Gishu County. Farmers were grouped into homogenous sub-sets (wheat and maize farmers) across the six Constituencies of the study area. A purposive sampling design technique was utilized to select grain farmers across the six Constituencies of the county. The study concentrated on a sample of 164 grain farmers arrived at using statistical formula illustrated below.

$n=\frac{z^{2} p \cdot q}{d^{2}}$

Where:

$n=$ the desired sample size.

$z=$ the standard normal deviation at 0.05 significance level.

$p=$ the proportion in the target population estimated to have characteristics being measured.

$q=1-p$

$q=$ proportion of the sampled population in the study area.

The $z$ - statistic at 1 level of significance is 1.282. Since there is no estimate available for the proportion in the target population that is assumed to have the characteristics of interest $(p), 50$ percent was used as recommended by Fisher et al (1983). Therefore, $p$ would be 0.5 . The level of significance, $d$ would be 0.05 . Therefore, the sample size, ' $n$ ' was calculated as:

$n=\frac{z^{2} p \cdot q}{d^{2}}$

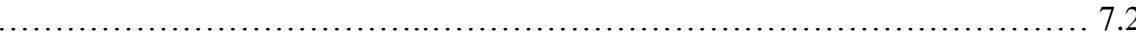

$n=\frac{\left(1.282^{2}\right) * 0.5 * 0.5}{\left(0.05^{2}\right)}$

7.2

.

$n=164$

. .7 .4$

\subsection{DATA TYPES AND SOURCES}

Both primary and secondary data were used. Primary data collected included farmer's age, gender, collateral, farmers' locality, marital status, Education level, interest rate charged, lending institution, farm size, repayment period, land ownership, family size, outputs, and others. This information was collected from financial institutions, ministry of agriculture reports and individual farmers.

\subsubsection{DATA COLLECTION INSTRUMENTS AND METHODS}

The study used structured questionnaires, interviews, observation and document analysis as the main tools for collecting data. The selection of these tools was guided by the nature of data to be collected, the time available as well as the objectives of the study.

\subsection{DATA ANALYSIS}

The questionnaires were edited; coded and quantitative data analyzed using descriptive statistics such as percentages, tabulation and frequency distribution. A binary logit, model which best fits this analysis was employed. Secondly, inferential analysis was utilized using logistic regression analysis $(\mathrm{R})$, where the maximum likelihood tool was used to analyze the binary model.

\section{Results And Discussions}

The study indeed, found out that 34.04 percent of those farmers with over 50 years accessed agricultural credit as compared to 4.26 percent of 20-29 years of age who accessed credit. About 34.04 percent of those aged 30-39 years and 27.66 percent of farmers aged 40-49 years accessed credit. This clearly shows that farmers aged between 30-39 years and those above 50 years easily accessed agricultural credit than those of 
between 20-29 years and 40-49 years farmers. It seems age of the farmer is taken by financial institutions as an important parameter in approving loan applications. Similarly, age is considered as a measure of maturity and degree of hard work. Therefore, the middle age farmers are presumed by the financial institutions as more responsible and mature, hence given a loan they can invest wisely, resulting to prompt repayment. While, on the other hand young farmers are considered less responsible by the financial institutions and as a result have high chances of defaulting loans. Additionally, older farmers of over 50 years are considered to be experienced in farming and utilizing credit. So, the existing financial institutions in the study area tend to approve most of the loans from farmers aged 30-39 years and those of above 50 years than for the others as shown in figure 8.1.

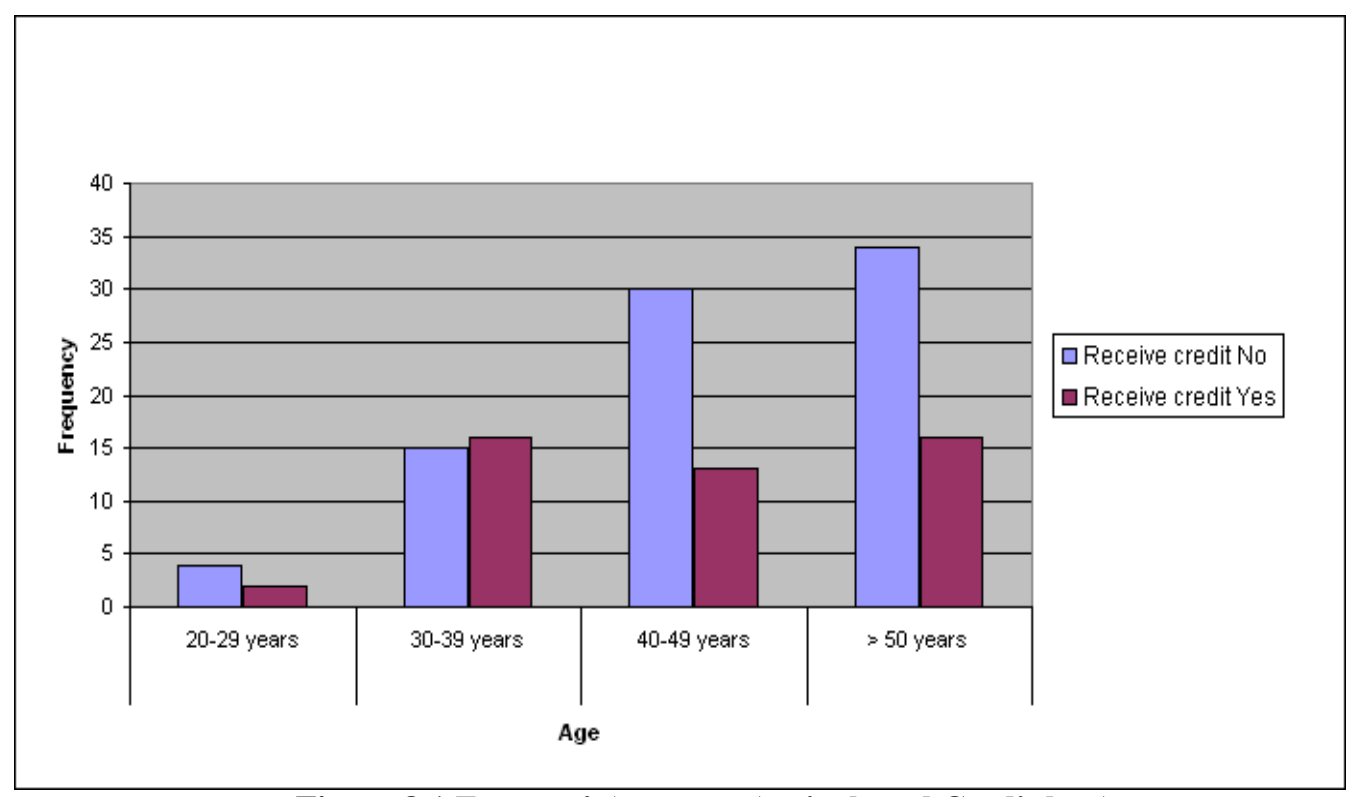

Figure 8.1 Farmers' Access to Agricultural Credit by Age

Source: Computed from the field data, 2012

The gender of farmers involved in the study comprised mainly of the male compared to their female counterparts as summarized in Figure 8.2. Gender was included because males are known to have greater access to agricultural credit than females in most financial markets. In the informal arena, women in rural areas are known to have a greater access to credit facilities than males (Hussein, 1988). Male farmer accessed agricultural credit than their female counterparts at 78.72 percent and 21.28 percent respectively. This shows that most of the decisions on accessing agricultural credit are mainly made by male in the three financial institutions. The implication is that male headed households had more access to agricultural credit than their female counterparts could be due to the fact that land ownership is dominated by male. This is attributed to collateral security which is a requirement by financial institutions and is traditionally owned by male farmers. Indeed, this makes the gender variable an important determinant in accessing agricultural credit, where the female headed households are credit constrained.

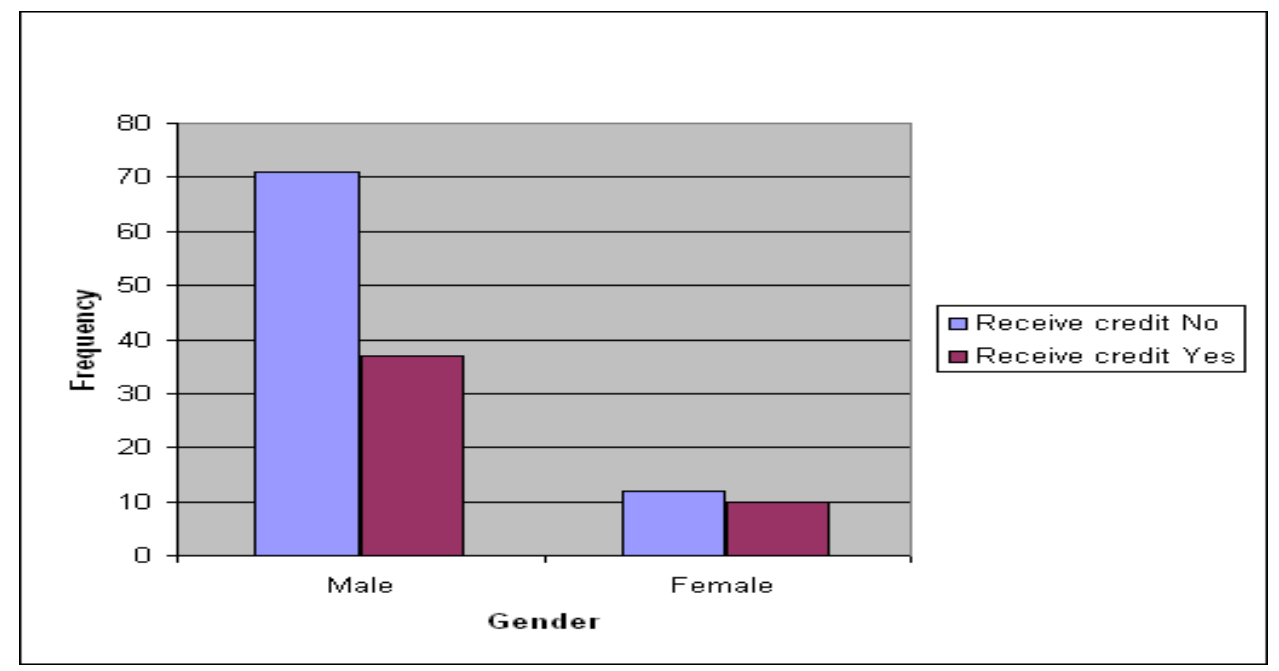

Figure 8.2 Farmers' Access to Agricultural Credit by Gender 
Source: Computed from the field data, 2012

Higher levels of education imply better technical knowledge, know-how and farming skills, more information on credit markets and facilities and familiarity with bureaucratic procedures. It was evident that educated farmers who had secondary education accessed agricultural credit than those with post secondary and primary education at 51.06 percent, 21.28 percent and 27.66 percent respectively as shown in Figure 8.3.

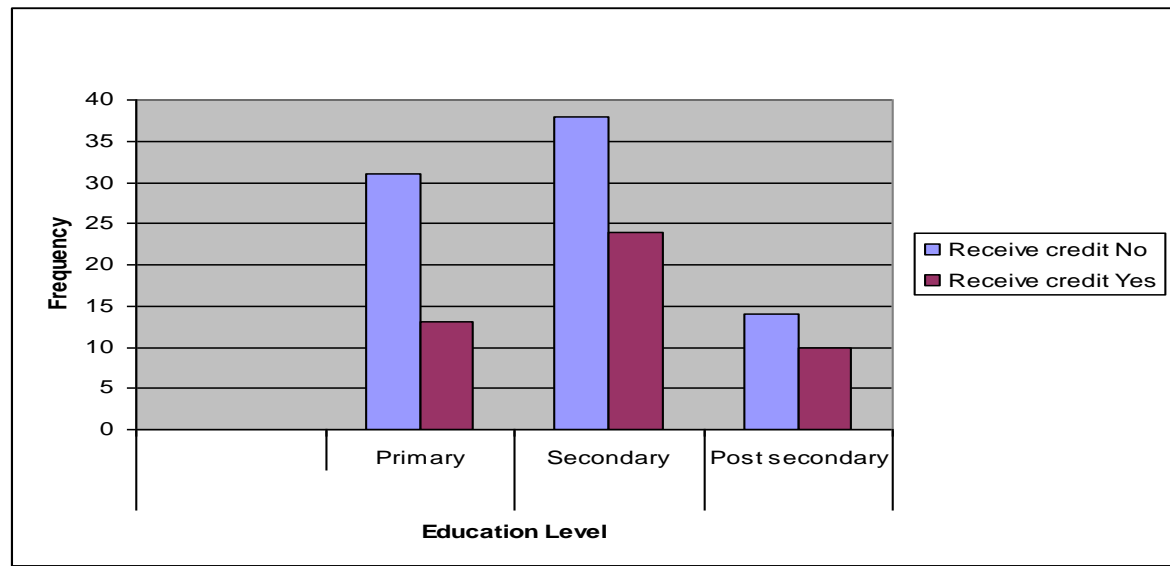

Figure 8.3 Farmers' Access to Agricultural Credit by Education Level

Source: Computed from the field data, 2012

This may probably mean that farmers with secondary level of education are more conversant and with information which helps them easily associate with credit sources and better technologies of farming. A better education level a farmer has implies better understanding of employing superior techniques that can improve productivity, hence repaying credit promptly. While farmers who have higher level of education do not associate themselves so much with agricultural credit, since most of them are in employment or engage in productive businesses that enable them to raise capital for farming. Also financial institutions considers this group to have good sources of income hence are not prioritized in loan approvals. The other groups of farmers with primary level of education have limited information on credit market and are risk averse. As a result financial institutions ration them from accessing agricultural market.

Farm size was measured in acres. It was used to estimate the expected income of the borrower and also used as a proxy for the scale of operation of the borrowers being classified into the different groups. Large farm sizes were expected to lead in accessing agricultural credit as compared to small farms. The bigger the farm size, the more likely it is that grain farmer would obtain loans. Larger farm size affects the amount of the loan needed through a greater need for variable cash inputs, hence increasing the need for credit (Sial \& Carter, 1996). Transaction cost associated with many small loans acted as disincentive for lenders and the cost of credit to small farmers is likely to increase. The presence of fixed transaction costs, the cost of borrowing in the formal credit market is therefore a declining function of the farm size (Mbowa and Nieuwoudt, 1999: 337; Binswanger et al, 1992:26). From the results of the study it showed that transaction cost varied depending on loan size and not farm size, contrary to Binswanger et al, 1992, of a declining function on farm size. Land is a vital resource to farmers. In the study area, there was major difference in the mean land holding of formal credit beneficiaries and non- beneficiaries households. The land size owned by grain farmers varied from one division to another as shown in Figure 8.4.

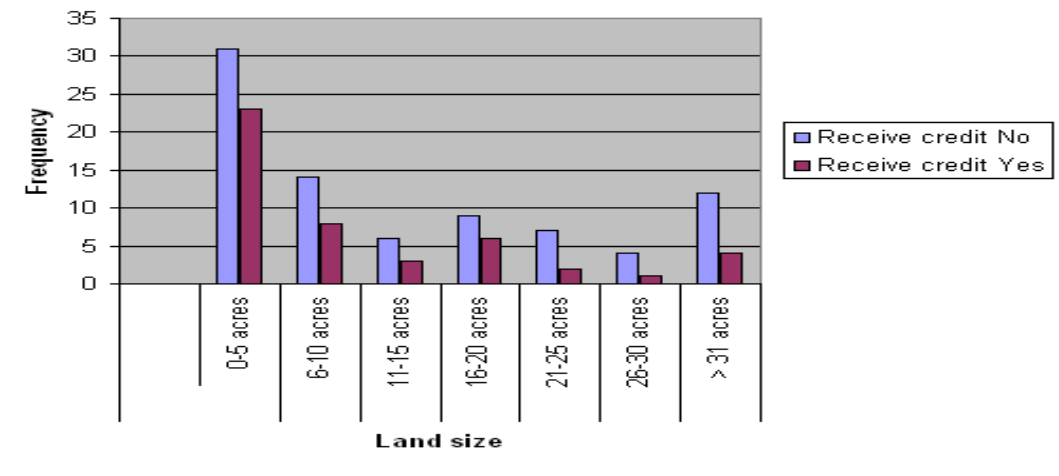

Figure 8.4: Farmers' Access to Agricultural Credit by Land Distribution among Households 
Source: Computed from the field data, 2012

48.93 percent of grain farmers who owned between 0.1-5 acres of land, 17.02 percent of the farmers who own between 6-10 acres, 6.38 percent of those who own between 11-15 acres, 12.77 percent of the grain farmers who own between 16-20 acres, 4.26 percent of those who own 21-25 acres, 2.13 percent of the farmers who have 2630 acres and 8.51 percent of the grain farmers who had over 31 acres accessed agricultural credit. It is clear from the results that most of the grain farmers are small-scale holders of between 0.1-5 acres comprises 41.54 percent of the total farmers sampled, 16.92 percent had 6-10 acres, 6.92 percent had 11-15 acres, 11.54 percent had 16-20 acres, 6.92 percent had 21-25 acres, 3.85 percent had 26-30 acres and 12.31percent had over 31 acres of land. Though most grain farmers are small- scale farmers, it is evident in the results that medium to large scale farmers accessed agricultural credit as opposed to small scale counterparts.

Land ownership is a critical parameter in general development of any area. Individual ownership of land improves the ability of a farmer to obtain loans. Ownership, as opposed to lease, rental or the use of communal lands, increases the size of the loan because it may increase long run investment incentives and the collateral value of the land to lenders (FAO, 2003). These confirm that the pledging of land collateral significantly increases the amount of credit offered by institutional lenders as compared to cases where there is no collateral. Farmers who own land privately accessed agricultural credit than those of leasehold, renting and communal at 89.36 percent, 0 percent, 2.13 percent, and 8.51 percent respectively as shown below.

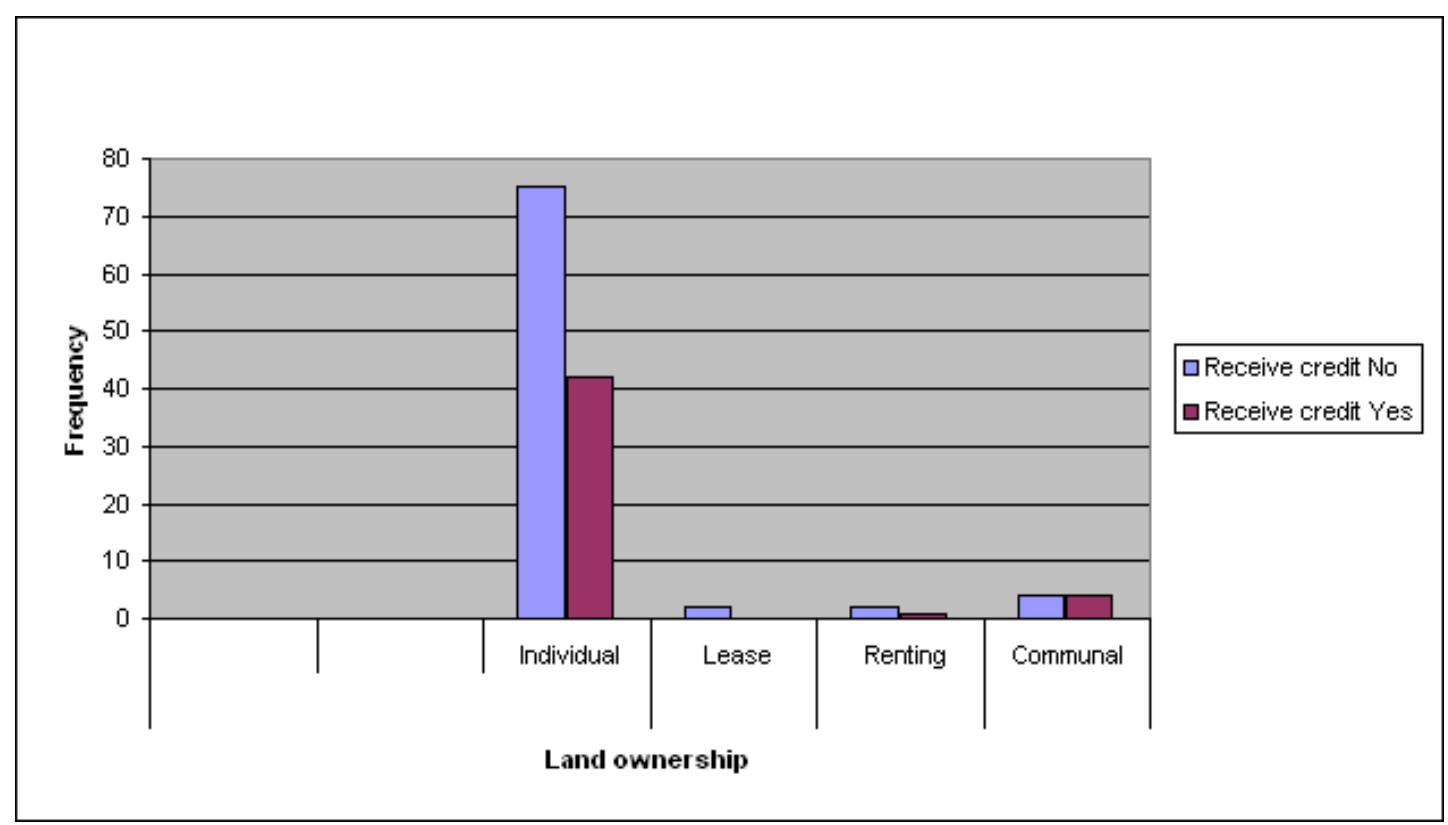

Figure 8.5: Farmers' Access to Agricultural Credit by Land Ownership Status

Source: Computed from the field data, 2012.

This implies that access to agricultural credit is influenced by private land ownership, since they have sole ownership hence full rights to use or commit the collaterals they have in order to obtain credit.

The maximum repayment period from both AFC and MFI for most cases has been limited to one year. Though there are instances were some farmers take development loan, which is repaid over a period of 10 years. Moreover, the repayment time for agricultural credit is immediately after crops are harvested and since the harvesting time for most grains is at the end of the year in the study area. Prompt repayment is a challenge to most financial institutions, since the ability to repay credit may not be uniform overtime. This also affects farmers' lack of continual access to agricultural credit, when appraisals are done. In the results 12.76 percent of the farmers who repaid their loan in one year accessed agricultural credit, 2.13 percent in more than one year, 2.13 percent in six months, 2.13 percent in three months and 80.85 percent of the grain farmers who repaid their loans in unspecified time did access agricultural credit as shown in Figure 8.6. 


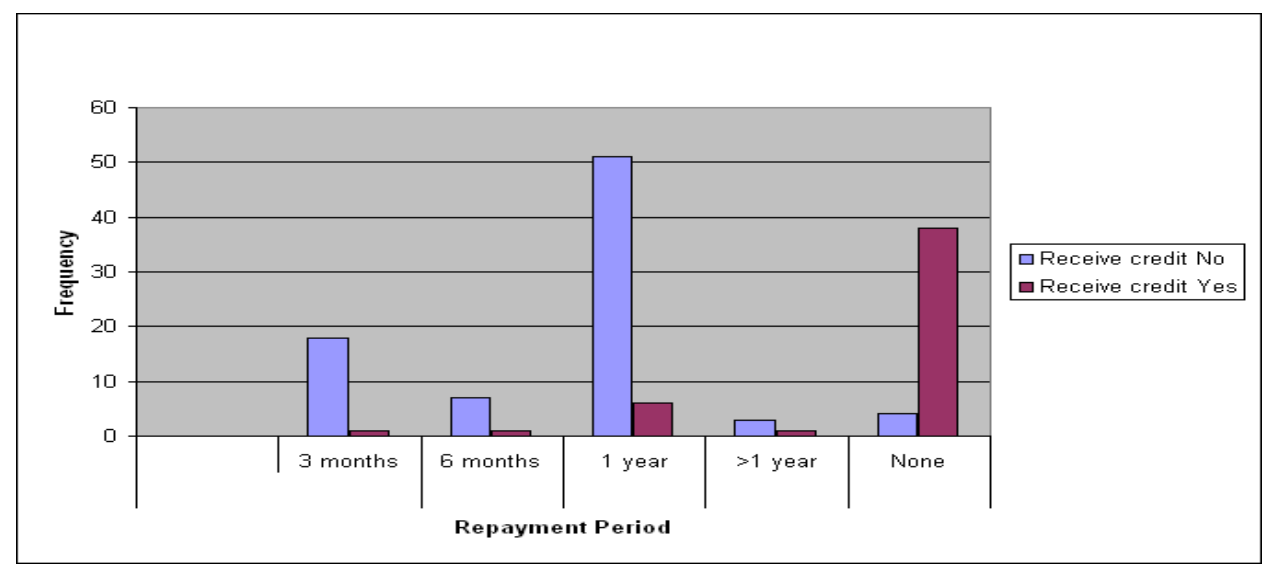

Figure 8.6 Farmers' Access to Agricultural Credit by Repayment Period

Source: Computed from the field data, 2012

The higher percentage in the number of grain farmers who access credit may be due to the flexibility of repayment schedule (unspecified period), where farmers continuously negotiate with financial institutions on how to repay depending on the availability of funds. The results revealed that farmers who repay their loans in less than 1year accounted for a smaller percentage in accessing agricultural credit as compared to those of more than 1 year. This could have been as a result of strict time lines in repaying the loans; hence most farmers end up not repaying on time and agreed terms.

The income was used as a proxy for the ability of the borrower for self-finance. This variable connotes the need for enterprise viability or profitability as a key decision variable in credit provision by the financial institutions. The major sources of farmers income included; formal employment, farming and business as shown in Figure 8.7 .

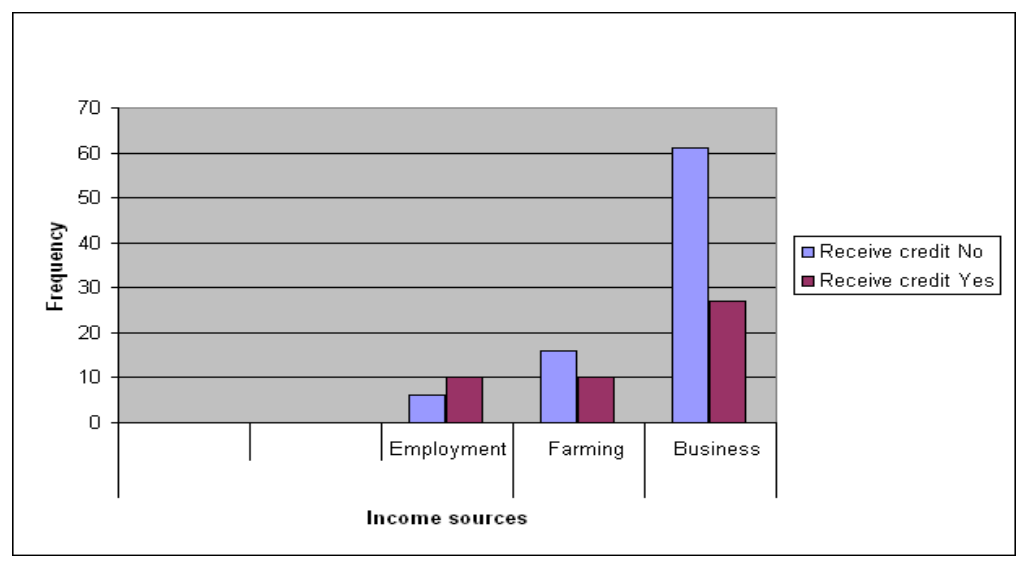

Figure 8.7 Farmers' Access to Agricultural Credit by Major Sources of Income

Source: Computed from the field data, 2012.

A socio-economic comparison based on the credit status of grain growers indicates that beneficiaries have significantly higher resource endowment than non beneficiaries. A similar trend was observed on farmers with more than five acres of cultivated land as compared to those with less than 5 acres. Those with farm size greater than five acres had higher socio-economic values in farm income, savings, area cultivated and production. Farmers who engaged in business had 57.44 percent accessing agricultural credit as opposed to 21.28 percent of those in formal employment and farming. The possible reason why grain farmers who were business men accessed agricultural credit than those in formal employment and farming is the high turnover associated with business. Financial institutions consider farmers with a business orientation as having an advantage since they are able to plough back the returns faster than those who have no business orientation. Indeed financial institutions consider farmers whose major source of income is business as having a steady flow and quick rate of return; therefore in cases of crop failure this group of farmers can service the loan promptly, as opposed to those in formal employment and farming. Similarly, farmers with business orientation can utilize their high returns to buy required inputs that translate to increased productivity per unit area in the farm.

Dependency ratio is the number of dependents divided by the number of those working in the household. The level of agricultural commercialization is conceptualized as the ratio of the average value of output(s) marketed to the average value of total output(s) (von Braun and Kennedy, 1994). It embodies the concept of marketable surplus and market orientation of the households to agricultural production and their links to the market 
economy. It is used to determine and subsequently to classify the households as being market oriented/commercialized or not. Family members may substitute labour for cash inputs such as family labour and use off-farm income to purchase farm inputs hence reducing the need for credit. Figure 8.8 shows the family size of the sample respondents.

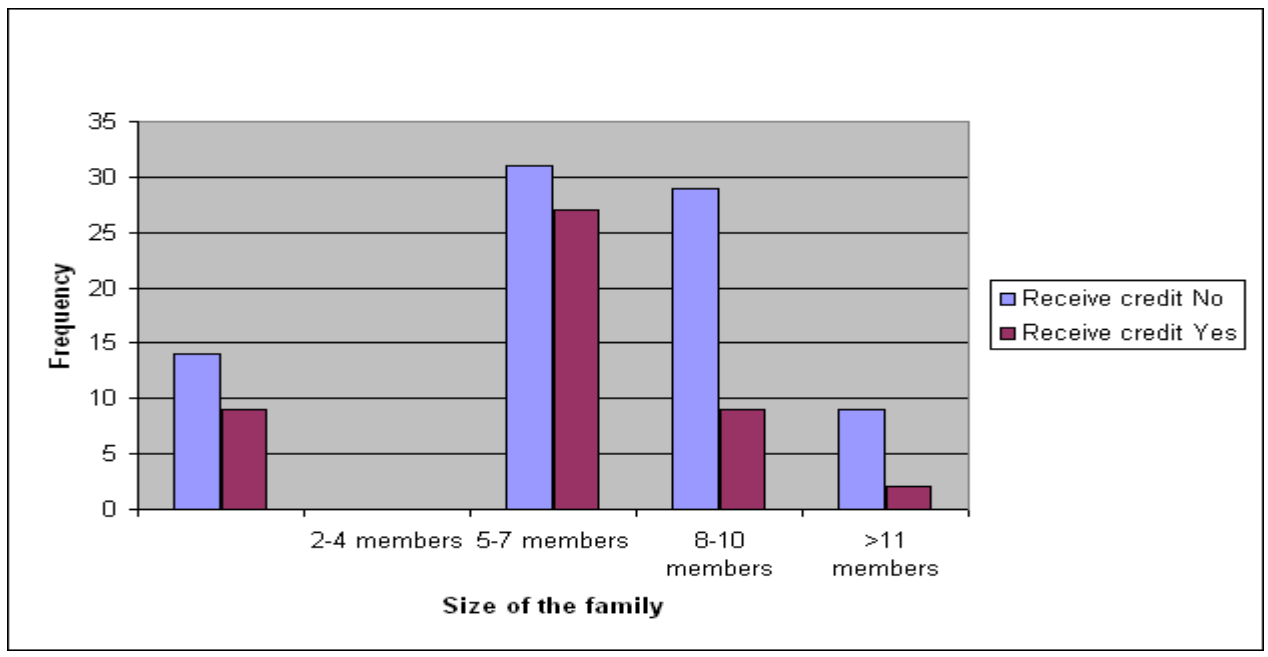

Figure 8.8 Farmers' Accessibility to Agricultural Credit by Size of Family

Source: Computed from the field data, 2012.

The largest family size had more than 11 members and the smallest was between 2-4 persons. Accordingly, the average family size of the sampled grain farmers who accessed agricultural credit more were found to be between 5-7 persons, followed by 2-4 members and 8-10 members and lastly those of more than 11 members were 57.45 percent, 19.15 percent, 19.15 percent and 4.25 percent respectively. From the analysis smaller to medium households accessed agricultural credit than bigger households. This is because smaller households tend to utilize their loans on the intended purpose as opposed to bigger ones.

The accessibility of agricultural credit by farmers' on the basis of average maize yield varied as shown in Figure 8.9 .

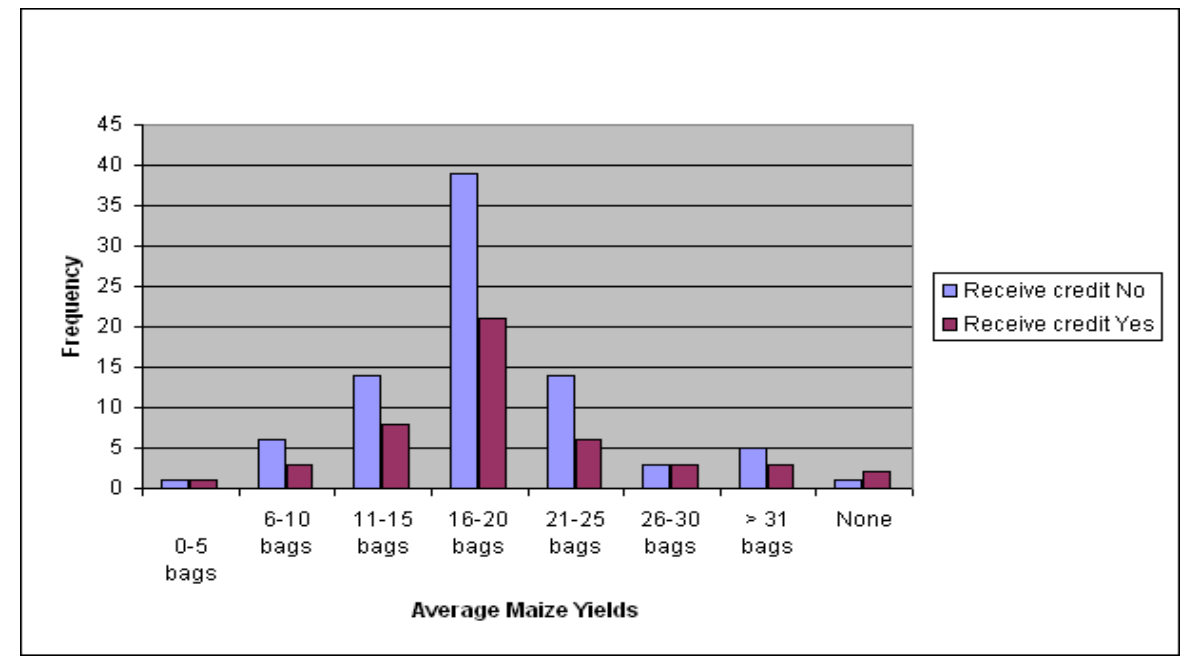

Figure 8.9: Farmers' Access to Agricultural Credit by Maize Yields

Source: Computed from the field data, 2012.

The highest yield of maize were above 31 bags/acre with 4 farmers receiving credit out of 9 who had applied (44.44 percent), followed by 26-30 bags/acre comprising of 3 grain farmers receiving agricultural credit from the 6 who had applied (50 percent), 21-25 bags/acre had 8 beneficiaries out of 22 applicants (accounting to 36.36 percent), those farmers who harvested between 16-20 bags/acre had the highest applicants and beneficiaries of 61 and 21 respectively representing 34.42 percent of beneficiaries, 11-15 bags/acre had a total of 22 farmers who had applied for credit, but only 8 benefited representing 36.36 percent, those who harvested between 6-10 bags/acre had 9 applicants of which 3 managed to get credit representing 33.33 percent, only 1 farmer applied for credit in the group who harvested between $0.1-5$ bags/acre but none managed to receive credit representing 0 percent. The general trend for the grain farmers' who accessed agricultural credit in 
relation to the average maize yields category were as follows $0.1-5$ bags/acre ( 0 percent $), 6-10$ bags/acre (6.38 percent), 11-15 bags/acre (17.02 percent), 16-20 bags/acre (44.68 percent), 21-25 bags/acre (17.02 percent), 2630 bags/acre ( 6.38 percent), above 31 bags/acre ( 8.52 percent). From these results it is clear that grain farmers who accessed agricultural credit were those who harvested an average of 16-20 bags per acre.

Most farmers (72.34 percent) applied for agricultural credit from financial institution, while 26.66 percent did not apply for any agricultural credit in the financial institutions as shown in Figure 8.10.

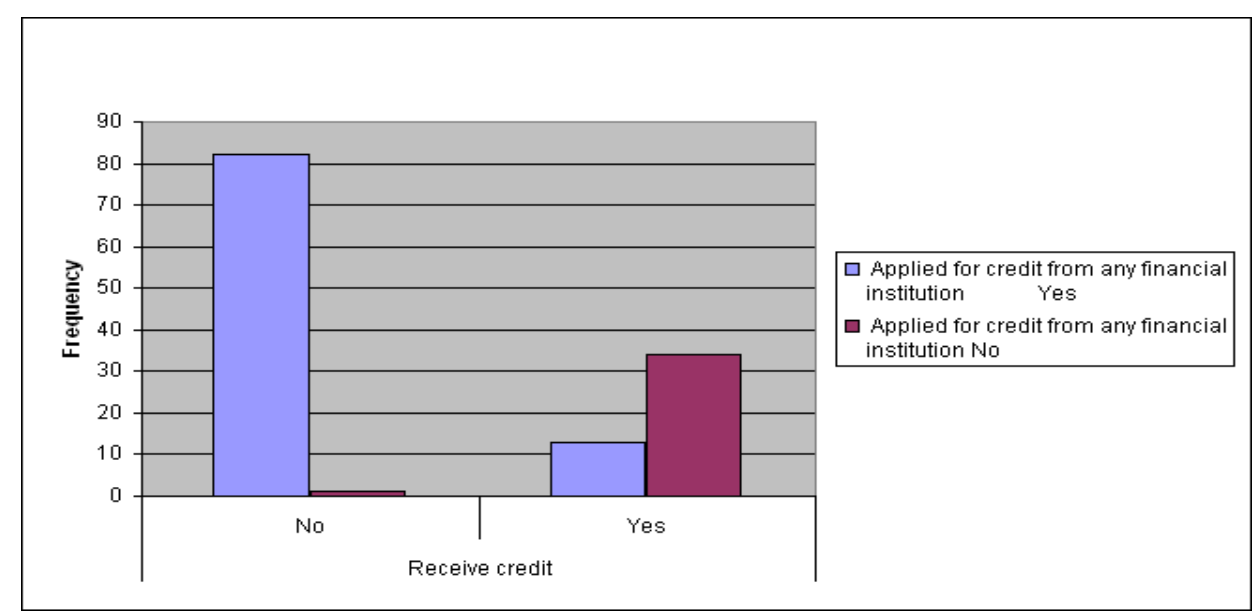

Figure 8.10: Farmers' Access to Agricultural Credit from any Financial Institution

Source: Computed from the field data, 2012.

Interest rates charged by financial institutions that advanced agricultural credit to farmers in Uasin-Gishu County ranged from 10 percent to 12 percent. Results show that farmers who lacked collateral and accessed agricultural credit were 55.32 percent while 44.68 percent of the farmers who had collateral security accessed credit. From this analysis those farmers who accessed credit without collateral securities belonged to groups hence obtaining a group loan which does not require a security. Most of the farmers had positively perceived the interest rates charged by the micro finance institutions (MFIs) in their area. Though, the interest rates charged by the institutions were greater than that of AFC's, it was not a problem to access credit from the institutions. However, the loan size provided by the MFI was very little and could not meet the demand of farmers especially during peak agricultural seasons. Very low credit creates high demand on the limited agricultural credit, thus rationing credit among most farmers.

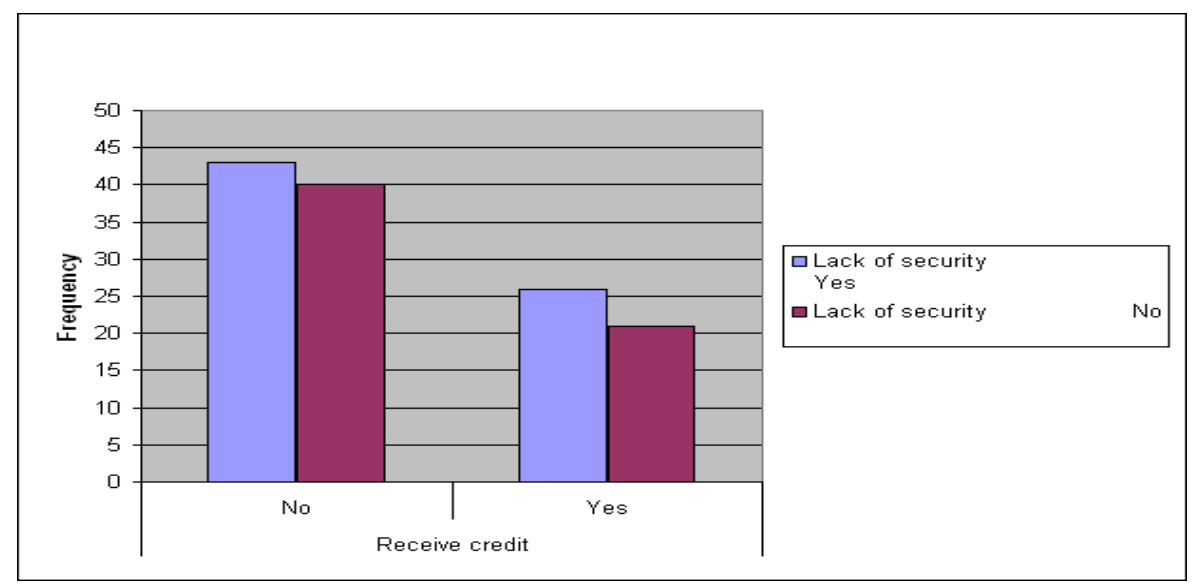

Figure 8.11: Farmers' Access to Agricultural Credit by their Lack of Security.

Source: Computed from the field data, 2012

The views of different farmers in the interest rate charged by financial institutions were almost homogeneous. High interest rate was identified by 86.2 percent of the farmers to limit accessibility to credit, while 13.8 percent were of contrary opinion. Thus the financial gap that leads farmers to borrow from private money lenders at higher interest rate.

The study showed that 47 farmers had accessed credit while 83 did not. The study predicted that if each farmer did not access credit, then this prediction would be correct 83 times out of 130 (63.8 percent) as shown in table 8.1 . 
Agricultural Credit Access By Grain Growers In Uasin-Gishu County, Kenya.

Table 8.1: Proportion of Respondents who received \& did not receive Credit

\begin{tabular}{|c|c|c|}
\hline Received Credit & Frequency & Percentage \\
\hline Yes & 47 & 36.2 \\
\hline No & 83 & 63.8 \\
\hline Total & 130 & 100 \\
\hline
\end{tabular}

But if the study had predicted that each farmer accessed credit, then these predictions would be correct 47 times out of 130 (36.2 percent). The classification output of a model that includes only the intercept, given the base rates of the two access options, 63.8 percent did not receive agricultural credit while 36.2 percent accessed credit, and no other information, the best strategy would be to predict, for every case, that the farmers did not access credit. Using this strategy, then it was correct to predict 63.8 percent of the grain growers in the greater Uasin-Gishu County did not access agricultural credit. The regression results of variables influencing access to agricultural credit are summarized in table 8.2 which shows the estimates predicted in the model.

Table 8.2: Regression Results

\begin{tabular}{|c|c|c|c|c|c|}
\hline $\begin{array}{c}\text { Explanatory } \\
\text { Variables }\end{array}$ & $\begin{array}{c}\text { Estimated } \\
\text { Coefficient(B) }\end{array}$ & S.E. & Wald & Sig. & Odds Ratio/Exp(B) \\
\hline Gender & 2.241 & 1.205 & 3.459 & $0.063^{*}$ & 9.406 \\
\hline Age & 2.354 & 1.106 & 4.526 & $.033^{* *}$ & 10.523 \\
\hline Education & 1.664 & 0.832 & 4.004 & $.045^{* *}$ & 5.282 \\
\hline Family size & -1.404 & 0.816 & 2.965 & $0.085^{*}$ & 0.246 \\
\hline Family living & 1.164 & 0.653 & 3.175 & $0.075^{*}$ & 3.202 \\
\hline Land size & -0.450 & 0.337 & 1.784 & 0.182 & 0.637 \\
\hline Land ownership & 1.074 & 0.656 & 2.680 & 0.102 & 2.928 \\
\hline Income sources & 0.656 & 0.695 & 0.892 & 0.345 & 1.927 \\
\hline Maize yield & 0.402 & 0.382 & 1.107 & 0.293 & \\
\hline Applied loan & 8.811 & 2.716 & 10.520 & $0.001^{* * *}$ & 6706.752 \\
\hline Repayment period & 0.987 & 0.360 & 7.491 & $0.006^{* * *}$ & 2.682 \\
\hline Collateral Security & -1.010 & 1.014 & 0.992 & 0.319 & 0.364 \\
\hline Constant & -16.032 & 6.946 & 5.327 & 0.021 & 0.000 \\
\hline
\end{tabular}

(*** and ** represent level of significant at 1, 5 percent respectively).

Source: Computed from the field data, 2012

The results indicated that all the variables in the equation (Variable(s) entered on step 1: education, land size, security, age, gender, land owner, income, apply loan, repayment, interest, farming's, maize yield, were significant predictors of accessibility to credit. The $\operatorname{Exp} B$ can be interpreted in terms of the change in odds. If the value is greater than 1 , then it indicates that as the predictor increases, the odds of the outcome occurring increases. These were seen for the gender, family living, age, education, land ownership, income, apply loan, repayment of loan and maize yield. The odds of outcome occurring were as follows; gender 9.406 times, family living 3.202 times, age 10.523 times, education level 5.282 times, land ownership 2.928 times, income sources 1.927 times, apply loan 6706.752 times, repayment of loan 2.682 times and maize yield 1.495 times. Conversely, a value less than 1 indicates that as the predictor increases, the odds of the outcome occurring decreases and these were evident in land size, family size and security.

According to Basant (1997), a positive significant coefficient on a variable for a particular variable indicates that the variable is associated with a higher probability of prediction. However, a negative significant coefficient means a lower probability of prediction. He further argued that coefficients that are not significantly different from zero whether positive or negative indicate that, the particular regressor $\left(\mathrm{X}_{\mathrm{i}}\right)$ does not affect the utility or the probability of prediction.

The predictive factors which had positive coefficient include: gender, age, education, land ownership, income, apply loan, repayment of loan and maize yield. Predictive factors which had a negative coefficient include; land size, security, and family size. The results revealed that age and education were found to be significant at 5 percent while applied loan and repayment period was statistically significant at 1 percent level. However, land ownership, income sources, maize yield, land size, collateral security was not significantly different from zero.

It was hypothesized that the probability of the agricultural credit institutions deciding on a particular outcome depends on the age of the borrower (the experience of grain growers in farming and sourcing finances). This was used as a proxy for maturity, the potential for careful handling of the loans and the repayment capability of the borrower. The results shows that farmers' age had a positive coefficient and was significantly related to the dependent variable at 5 percent level of significance. The odds ratio favouring access to agricultural credit increases by a factor of 10.523 for an increase in farming experience. This result is consistent with Atieno (2001), who found out that past credit participation was a significant variable to explain farmers' participation in both formal and informal credit markets. 
The Wald statistics corresponding to gender variable was statistically significant at 5 percent level and had a positive coefficient. The odds ratio favouring access to agricultural credit increases by a factor of 9.406 for male farmers. This study is not in tandem with Hussein, (1988) were in the informal arena, women in rural areas are known to have a greater access to credit facilities than males. Male farmers had a high chance (83.1 percent) of accessing agricultural credit than female farmers (16.9 percent) in the study area.

The results of the model show that education level positively affects access to agricultural credit by grain growers and were significant at 5 percent level of significance. Higher levels of education imply better technical knowledge, know-how and farming skills, well connected, more information on credit markets and facilities and familiarity with bureaucratic procedures. It was evident that educated farmers (secondary level were 47.7 percent) were more likely to access agricultural credit judiciously than the less educated ones (Primary level were 33.8 percent). The odds ratio favouring access to agricultural credit increases by a factor of 2.632 for more educated farmers.

Farm size was measured in acres. It was used to estimate the expected income of the borrower and also used as a proxy for the scale of operation of the borrowers being classified into the different groups. Large farm sizes were expected to lead in accessing agricultural credit. The farm size had a negative size and not significant at 10 percent. The bigger the farm size, the more likely it is that farmer would obtain loans. Larger farm size affects the amount of the loan needed through a greater need for variable cash inputs, hence increasing the need for credit (Sial \& Carter, 1996). These results are contrary to the results of (Sial \& Carter, 1996 and Feder et al, 1988). Transaction cost associated with many small loans acted as disincentive for lenders and the cost of credit to small- scale farmers is likely to increase. The presence of fixed transaction costs, the cost of borrowing in the formal credit market is therefore a declining function of the farm size (Mbowa \& Nieuwoudt, 1999: 337; Binswanger et al, 1992:26). From the results it showed that transaction cost varied depending on loan size and not farm size, contrary to Binswanger et al, 1992, who found the contrary. The odds ratio favouring access to agricultural credit decreases by a factor of 0.637 as the land size reduce.

Land ownership has a positive sign and is statistically insignificant at 10 percent. Individual farm ownership of land improves the ability of a farmer to obtain loans. As such individual ownership, as opposed to lease, rental or the use of communal lands, increases the size of the loan because it may increase long run investment incentives and the collateral value of the land to lenders (FAO, 1999). This confirms that the pledging of land collateral significantly increases the amount of credit offered by institutional lenders as compared to cases where there is no collateral. Indeed, the odds ratio favouring access to agricultural credit by grain farmers increases by a factor of 2.9 for those who owned land individually.

The Wald statistics of family size was had a negative coefficient and the odds ratio favouring access to agricultural credit by grain farmers decreases by a factor of 0.246 for big family sizes. The results indicate that, farmers who had applied for agricultural credit greatly affected access to agricultural credit. The variable was significant at 1 percent and the odds ratio favouring access to agricultural credit increases by a factor of 6706.752 for those who applied. The bigger odds ratio shows farmers who apply for credit stand higher chances of accessing loans than those who have not applied. This calls for farmers to apply for credit even if they did not receive it previously.

The number of family members staying in the household had a positive coefficient and which was statistically significant at 10 percent. The odds ratio favouring access to agricultural credit increases by a factor of 3.202 for smaller numbers. Many family members staying in the household, translates to higher consumption. Hence, creating leakages on the borrowed loans, that results in delayed repayments or complete defaults. The results clearly show that, if there are more young children and older members in the household then, there is a higher chance of having many consumers than producers. This will affect proper utilization of credit acquired and as a result hinders future credit access by such households.

Lack of collateral, credit rationing and high default rate were all ranked first, among the difficulties in applying for credit. Thus, it appears that collateral requirement was statistically insignificant at 5 percent and had a negative coefficient. The odds ratio favouring access to agricultural credit decreases by a factor of 0.364 for lack of a collateral security. This could be so, as a result of most farmers embracing group loans which do not require collateral security.

The maximum repayment period from both AFC and MFI for long has been limited to one year. Repayment period had a positive coefficient and was statistically significant at 1 percent level of significance. Indeed, the odds ratio favouring access to agricultural credit increases by a factor of 2.614 for farmers who repay their loans immediately.

Income was used as a proxy for the ability of the borrower to self-finance in farm operations. This variable connotes the need for enterprise viability or profitability as a key decision variable in credit provision by the financial institutions. Income had a positive coefficient but was not statistically significant at 5 percent level of significance. The odds ratio favouring access to agricultural credit by grain growers increases by a factor of 1.927 for higher income source. Maize yields were statistically insignificant at 5 percent. Maize yields 
had a positive coefficient with an odds ratio favouring access to agricultural credit increasing by a factor of 1.495 for high yields.

\section{Findings}

It is clear from the results, that many financial institutions favoured mostly male farmers than female farmers in advancing agricultural credit. Indeed, experience was found to be a key issue in most assignments, were it is taken as a measure of trust or capability to handle responsibilities. Educated farmers were found to access credit than less educated. This may have been because they are privy to more information on credit matters than less educated ones. The results indicate that average family sizes had a higher tendency in obtaining agricultural credit than larger and smaller ones. This contradicts the principle of dependency ratio (the number of dependents to those working in the household). Therefore, financial institutions are not supposed to use this parameter in awarding loans. But instead base their disbursement on the general capability of the applicant as an individual per se.

These inflexible repayment arrangements are not common with less educated farmers, since it entails lobbying with credit officers every time the loan is due. It may also be as a result of their ease in accessing information.

\section{Recommendations}

So as a remedial measure, high emphasis should be given in screening general potential borrowers irrespective of their gender. In pursuant of these agricultural extension officers at each sub-location should do a participatory wealth ranking for both male and female headed households, which will be later forwarded to the financial institutions, Ministry of Agriculture and Ministry of Planning and Vision 2030. Such, wealth ranking list will be used to solve the existing gender inequality in disbursing agricultural credit in future.

Proper database of grain farmers' age should be done by the department of Registrar of persons, then forward it to the agricultural extension officers to ascertain if indeed older farmers have succeeded in managing finances than young farmers. With such accurate findings on the age factor in relation to success in managing finances is fully documented, and then forward to credit institutions and Ministry of Agriculture for ratification and use.

Ministry of Information and Communication in conjunction with credit and extension officers should contact frequent civic education on credit access, management and enterprise selection. The officers are to use face to face, electronic and print means of communication so as to reach less educated farmers. Agricultural extension officers should intensify dissemination of credit information to all grain farmers in their respective sub-locations. This can be done by regularly holding seminars and public barazas with grain farmers on the benefits of applying agricultural credit, proper use and prompt repayment.

Ministry of Agriculture through extension officers should identify and document other alternative income sources of all the grain farmers in each sub-location. This information will be given to all lending institutions in the study, for use when awarding and subsequently in repaying loans. Financial institutions will use such information in assisting farmers who have little information on dynamics of agricultural credit, to repay using those other alternative incomes. Eventually the farmers who might have become defaulters or laggards in repaying will be advised on how to repay outside the official arrangement.

The government should come out to defend vulnerable groups as per National land policy, so that they may be given a chance to inherit land rights, to boost their chances of accessing credit.

\section{Conclusions}

The results revealed that majority of the farming households' especially female headed households did not access agricultural credit. Indeed in the sampled households, an overwhelming male grain farmers' access agricultural credit than females. This was seen to be attributed to a requirement by most financial institutions that collateral presented, for one to be considered for credit. But since land ownership is passed from father to son then female farmers would not have collateral (title deed) to present as security when sourcing for credit. Farmers who were old were revealed by the results to have access to agricultural credit than young farmers. Age may have been taken by most financial institutions as a proxy for maturity and subsequently translating it as a high potential in handling of the borrowed loan and prompt repayment. Also, farmers' old age was taken as a measure of length of experience in farming and sourcing agricultural finances.

On the education level, the results showed that educated farmers accessed agricultural credit more than uneducated ones. Farmers were classified into three groups as those with primary, secondary and post secondary level of education. The results revealed that majority of farmers with secondary level of education accessed credit, followed by those with primary level of education and lastly those with post secondary education. This result may be attributed to the fact that farmers with secondary education have a better technical knowledge, farming skills, more information on credit markets and familiarity with bureaucratic procedures. On the other hand those with post secondary education do not associate themselves with agricultural credit since most of 
them are employed or engage in other businesses with high rate of return than grain farming. Households were grouped into four groups and the results found out that the household of average members accessed agricultural credit more than small and large households. Indeed larger and smaller farm households were found to have a low tendency in accessing agricultural credit in Uasin-Gishu County. Grain farmers were classified as those who apply and those who didn't apply for credit. The results revealed that farmers who had applied for agricultural credit accessed the facility than those who had not.

In the repayment period, farmers were grouped into those repaying after 3 months, 6 months, 1 year and more than 1 year. The results revealed that farmers who repay their loans in more than one year (mostly unspecified time) accessed agricultural credit more than those who repay in less than one year. Due to strict timelines, most farmers who were to repay in less than one year end up defaulting or delaying. This eventually spoilt their reputations with financial institutions and as a result reduced their ability to access credit in future.

\section{Scope For Further Research}

I strongly encourage other researches to study the trend in agricultural credit repayments in the same county and in future on other Counties of Kenya.

\section{Acknowledgement}

First and foremost let me praise and honour the almighty God for the opportunity and capacity given to me to realize my aspiration. Secondly, I thank Professor M.O. Odhiambo and Professor P.M. Nyangweso for their unreserved help and insightful guidance. I am also deeply grateful to the Ministry of Agriculture staff in Uasin- Gishu County, staff at AFC and K-Rep financial institutions for their help. Lastly, my sincere appreciation and thanks also goes to all my friends and relatives.

\section{Reference}

[1]. Adegeye, A.J and Ditto, J.S. (1985), Essentials of Agricultural Economics. Impact Publishers Economics Nigeria, Limited, Ibadan.

[2]. AFC, 2005. “Agricultural Finance Corporation Strategic Plan, 2005-2010.

[3]. Atieno, R. (2001). Formal and Informal Institutions' Lending Policies and Access to Credit by Small-scale Enterprises in Kenya: An Empirical Assessment. African Economic Research Consortium, Nairobi.

[4]. Basant, R. (1977), "Technology Strategies of Large Enterprises in Indian Industry some Explorations". World development, Vol. 25 No. 10 Pp. $1683-1700$.

[5]. Bigsten, A., Collier, P., Dercon, S., Fafchamps, M., Gauthier, B., Gunning, J.W., Oduro, A., Oostendrop, R., Patillo, C., Soderbom, M., Teal, F., and Zewfack, A., (2003). Credit Constraints in Manufacturing Enterprises in Africa. Journal of African Economics 12(1): 104-125.

[6]. Binswanger Hans, P. and Sillers, D.A. (1992) 'Risk Aversion and Credit Constraints in Farmers' Decision-Making: A Reinterpretation', Journal of Development/ Studies 20(1): 21.

[7]. Buvinic, Mayra, and Marguerite Berger, (1990) "Sex Differences in Access to a Small

[8]. $\quad$ Enterprise Development Fund in Peru," World Development, Vol. 18, No.5, 1990, pp. 695-705.

[9]. Carter, M. R. (1988). The Impact of Credit on Peasant Productivity and Differentiation in Nicaragua. Journal of Development Economics, 103: 13-36.

[10]. Chambers, E.A. and Cox, D.R. (1967). Discrimination Between Alternative Binary Response Models. Biometrika, 54,573-578.

[11]. Christen Robert P., and Douglas Pearce. (2005). Managing Risks and Designing Products for Agricultural Microfinance: Features of an Emerging Model. CGAP Occasional Paper, No.11. Washington, D.C.: CGPA.

[12]. Cramer, J.S. (1986). Econometric Applications of Maximum Likelihood Methods. Cambridge: Cambridge University Press.

[13]. De Janvry, A. and E. Sandoulet, (1995), Rural Poverty and differentiated rural development programs Rev. Econ; 18:3-36.

[14]. Diagne, A. Zeller, M. and Sharma, M. (2000). Empirical Measurements of Households' Access to Credit and Credit Constraints in Developing Countries: Methodological Issues and Evidence: International Food Policy Research Institute. Washington, D.C. U.S.A

[15]. Fleisig, H. (1995). The Power of Collateral. View Point. Washington D.C., the World Bank.

[16]. Free on line dictionary, encyclopedia, (2007). http://www.thefreeonlinedictionary .com/credit.

[17]. Hossain, M. (1988). Credit for the Alleviation of Rural Poverty: The Grameen Bank in Bangladesh. IFPRI Research Report, 65

[18]. Hussein Hamda, (2007). Farm Household Economic Behaviour in Imperfect Financial Markets, Doctorial Thesis, Swedish University of Agricultural Sciences, Uppsala.

[19]. Kashuliza, A.K. and J.G. Kydd., (1996). Determinants of Bank Credit Access for Small holder Farmers in Tanzania: A Discriminant Analysis Application. Saving and Development, 3: 285-97.

[20]. Kebede Koomsa, (1995). Agricultural Credit Analysis. National Agricultural Policy Workshop.

[21]. Kenya, Ministry of Agriculture. Economic Review of Agriculture. Nairobi: Government Printers, 2010.

[22]. Kenya, Ministry of Lands. Sessional Paper No. 3 of 2009 on National Land Policy. Nairobi: Government Printers, 2009.

[23]. Lynam. A Survey on Credit Use in Sub- Sahara Africa. The Standard Newspaper 30 June. 2007: 31

[24]. Lindsay, P. \& Norman, A.D. (1977). Human Information Processing: An Introduction to Psychology.

[25]. Manig W. (1996). The Importance of the Informal Financial Market for Rural Development Financing in Developing Countries: The example of Pakistan. The Pakistan Development Review, 35 (3): 229-239

[26]. Mbowa, S. and Nieuwoudt, W.L.,(1990). Economics of Scale for Small and Large Scale Sugar cane Farmers in Kwazulu- Natal. Agrekon, 38(3): 336-355.

[27]. Mohieldin S. and Write W. (2000). Formal and Informal Credit Markets in Egypt. Center for Economic Policy Research and University of Nottingham.

[28]. Okurut. N.A.Schoombee and S. Berg. (2005). "Credit Demand and Credit Rationing in the Informal Financial Sector of Uganda."South African J. Econ.73 (2005):883-497.

[29]. Penchansky, R. and Thomas, W. J., (1981). The Concept of Access: Definition and Relationship to Consumer Satisfaction. Medical Care, 19(2): 127-140 
[30]. Rao S.V.N., Rangnekar D.V., R. Dey and A.W. Van Den Ban, (1998). "Farmers' Perceptions of Innovations". (On line available on the World Wide Web www:http://library.wur.n1/file/wurpubs/wurpublikeatie-100360123-001.pdf.)

[31]. Schmidt, R.H. and Kropp, E. (1987). "Rural Finance Guiding Principles." GTZ, Eschborn.

[32]. Sial, M.H. and Carter M.R (1996). Financial Market Efficiency in an Agrarian Economy: Microeconomic Analysis of the Pakistan Punjab. The Journal of Development Studies, Vol.12(5) June 1996: 771-198.

[33]. Von Braun, J. and Kennedy, E. (eds) (1994). Agricultural Commercialization, Economic Development and Nutrition. Baltimore M.D. USA. The John Hopkins University press.

[34]. Zeller. M. (1994) "Determinants of Credit Rationing: a Study of Informal Lenders and Formal Credit Groups in Madagascar." World Develop.2291994):1895-1907. 